\title{
Kitap Tantma
}

TYB Akademi: Osman Turan ve Selçuklular Özel Sayısı, Yıl: IV, Eylül 2014, S. 12, 200 s. ISSN: 2146-1759.

Osman Turan (1914-1978) Türkiye'de Selçuklu tarihçiliği denildiğinde ilk akla gelen ilim adamlarındandır. 2014 yılının Osman Turan'ın 100. doğum yıldönümü olması vesilesiyle Türkiye Yazarlar Birlĭgi Akademi: Dil Edebiyat ve Sosyal Bilimler Dergisi bir "Osman Turan ve Selçuklular” özel sayısı hazırladı. 200 sayfa hacmindeki bu özel sayıda toplam on yedi yazar, araştırmacı ve akademisyenin Osman Turan ve Selçuklu tarihini konu alan makaleleri yayınland.

"Osman Turan ve Selçuklular” özel sayısının "sayı editörlüğü”nü Prof. Dr. Gülay Öğün Bezer yapmış. Dergide makalesi bulunan yazarlar ise şunlardır (yayınlanış sırasına göre): D. Mehmet Doğan, Abdurrahim Tufantoz, Gülay Öğün Bezer, Birsel Küçüksipahioğlu, Ebru Altan, Muallâ Uydu Yücel, Muharrem Kesik, Abdülkerim Özaydın, Sadi S. Kucur, Mustafa Alican, Emine Uyumaz, Ali Birinci, Salih Yılmaz, Murat Nalçacı, Celil Güngör, Fatih Gökdağ, Ali Birbiçer ve Albey Abazov.

Özel sayının ası itibariyle ilk yazısı Abdurrahim Tufantoz'un "Osman Turan’ın Hayatı (1914-17 Ocak 1978) ve Tarihçiliğ̣i” başlıklı yazısıdır (s. 11-19). İki fotoğrafla da desteklenen bu yazıda Osman Turan'ın doğum yeriyle ilgili birbirinden farklı bilgiler cem ve telif edilerek net bir sonuca ulaşılmış, meslekî hayatı yayınlanmış kitap ve makalelerden yola çıkılarak kronolojik bir biçimde verilmiş, peşinden de Osman Turan’ın tarihçiliğine ve eserlerine dair bilgi ve değerlendirmelere geçilmiştir. Tarihçiliğine ayrılan birkaç sayfada daha çok Selçuklu Tarihi alanına katkısı üzerinde durulmuş ve hemen peşinden üç önemli eseri (Selçuklular Tarihi ve Türk-İslâm Medeniyeti; Türk Cihan Hâkimiyeti Mefkûresi Tarihi; Selçuklular Zamanında Türkiye) tanıtılmıştır.

Dergideki diğer yazılar Selçuklu tarihinin çeşitli meseleleriyle ilgili olmakla birlikte bir de Osman Turan hakkında kapsamlı bir röportaja yer verilmektedir. TYB Akademi dergisinin bu sayısında alanın uzmanlarından bir kısım tarihçilerin şu makaleleri vardır:

Gülay Öğün Bezer “Anadolu'nun Fethi ve Drakon Çayı Anlaşması'nın Bu Süreçteki Yeri” başlıklı yazısında (s. 21-35) M. X. Yüzyılda batıya doğru gelişen Türk göçünün Anadolu'ya Selçuklu Türklerinin yerleşip devletleşmesine giden süreçte önemli bir durağı olan "Drakon Çayı Anlaşması"nı mercek altına almaktadır. Bu anlaşma Bizans İmparatoru Aleksios Komnenos ile Türkiye Selçuklu Sultanı Süleyman-şah arasında imzalanmıştır.

Doç. Dr. Birsel Küçüksipahioğlu'nun makalesi Selçuklular devrinin üzerinde pek durulmamış şahsiyetlerinden Mevdûd b. Altuntekin hakkındadır. Hâlbuki Mevdûd, Mükrimin Halil Yinanç’tan Prof. Dr. Ali Sevim’e varıncaya kadar Selçuklu tarihini araştırmış bütün tarihçilerin eserlerinde zikredilen bir şahsiyettir. Küçüksipahioğlu "Mevdûd b. Al- 
tuntekin: Haçlılarla Mücadele Eden Bir Selçuklu Komutanı” başlıklı yazısında (s. 37-63) yerli ve yabancı birçok kaynağa müracaat ederek Selçuklu tarihinde rol oynamış şahsiyetler arasında daha ikinci planda kalmış gözüken bu Selçuklu komutanını günümüz okuyucusuna tanitmaktadır.

Alanının uzmanlarından ve Türk Tarih Kurumu Yayınları arasında İkinci Haçlı Seferi (1147-1148 (2003) adlı bir eseri de bulunan Doç. Dr. Ebru Altan da Osman Turan Özel Sayısı'na katkıda bulunan akademisyenlerdendir. Altan, "Suriye Selçuklu Meliklerinin Haçlılarla İlişkileri”ni mercek altına aldığı yazısında oldukça kapsamlı bir konu olan Selçuklu-Haçlı ilişkilerini ana hatlarıyla ortaya koymaktadır.

Prof. Dr. Muallâ Uydu Yücel çalışma ve ilgi alanı doğrultusunda Selçuklu tarihinin çok üzerinde durulmadığını söyleyebileceğimiz bir yönünü ele almaktadır: "Selçuklu Çağında Kuman-Kıpçaklar” başlıklı makalesinde (s. 65-86) Anadolu'da Selçuklu tarihi oluşurken Balkaş Gölü'nden Tuna boylarına kadar yayılmış ve izler bırakmış Türk boylarından olan Kuman-Kıpçakların ne durumda oldukları hususuna eğilmektedir. Doğrusu Anadolu'da Selçuklu çağında diğer Türk bölgelerinin ne durumda olduğu ve bunlar arasında ne gibi bağlantılar bulunduğu hususu araştırılmaya değer bir konudur.

"Melik Şahinşah’ın Saltanat Mücadelesi (1155-1176)" başlıklı makalesinde (s. 89-99) Selçuklu tarihi çalışmalarında ismi sık sık geçen tarihî şahsiyetlerden biri olan Melik Şahinşah’ın Selçuklu devri içindeki yerini inceleyen Doç. Dr. Muharrem Kesik bu devir boyunca tekrarlanagelen Sultân öldükten sonra veliaht ve şehzade kardeşler arasında ortaya çıkan saltanat çatışmasının bir kesitini mercek altına almaktadır. Daha önce Türk Tarih Kurumu Yayınları arasında Türkiye Selçuklu Devleti Tarihi Sultan I. Mesud Dönemi (1116-1155), (2003) yayınlanmış bulunan araştırmacı, Sultan I. Mesud'un veliahdı II. Kılıç Arslan ile kardeşi şehzade Şahin-şah arasındaki kavgayı, bu makalesinde temel kaynaklardan yola çıarak aydınlatmaktadır.

"Nakîbü'n-Nukabâ" kavramını Selçuklu devrine ait bir örnekten yola çıkarak inceleyen Prof. Dr. Abdülkerim Özaydın genelde kurumlar tarihi, özelde İslâm kurumları tarihi alanına önemli bir katkıda bulunmaktadır. "Selçuklular Döneminde Nakîbü'nNukabâların Siyâsî, İdârî ve İçtimâî Hayattaki Rolleri: Tırâd b. Muhammed ve Oğlu Ali b. Tırâd el-Kureşî el-Hâşimî el-Abbâsî ez-Zeynebî Örneği” (s. 101-114) başlıklı yazısında Prof. Özaydın, Abbâsî-Selçuklu ilişkilerine "Nakîbü’n-Nukabâ" müessesesi üzerinden 1şık tutmuş olmaktadır.

Yine kurumlar tarihi alanına katkı sağlayacak bir makale Yrd. Doç. Dr. Sadi S. Kucur tarafindan kaleme alınmıştır. "Selçuklu Türkiyesi’nde Bir Mekân Adı: İrmanhâne” başlığını taşıyan bu makalede "irmanhâne" kavramının muhtevasından çok, doğru imlâsının nasıl olması gerektiği netleştirilmeye çalışılmaktadır.

Meyyâfârikîn şehir adı Selçuklu tarihi kaynaklarında sıkça geçmektedir. Diğer adı Silvan olan bu şehir, Selçuklu devri Anadolu'sunun önemli şehirlerinden biridir. Bugün 
Diyarbakır’ın bir ilçesi olarak varlığını sürdüren bu şehrin kuruluş tarihiyle ilgili araştırmalar ilgi çekici bir şehir tarihi çalışmasını önümüze koyacaktır. Yrd. Doç. Dr. Mustafa Alican'ın "Meyyâfârikîn (Silvan) Şehrinin Kuruluşu Üzerine Bir İnceleme" (s. 122-138) başlıklı yazısı bu şehrin kuruluşu konusunu ele alan kaynakları karşılaştırmalı olarak kullanan ve bir sonuca varmaya çalışan bir çalışmadır. Makaleden anlaşıldığı kadarıyla şehrin kuruluş tarihi Asurlular devrine kadar çıkmaktadır.

Defin ve taziye gelenekleri konusu ilk çağlardan başlayarak araştırmalara konu olmuş ve Türk Tarih Kurumu Yayınları arasında da bu alanda birkaç eser yayınlanmıştır. Kurum yayınlarından Tahsin Özgüç'ün Öntarih'te Anadolu'da Ölü Gömme Âdetleri (1945); İ. Metin Akyurt'un M.Ö. 2. Binde Anadolu'da Ölü Gömme Âdetleri (1998, 2014); Nevzat Çevik'in Urartu Kaya Mezarlan ve Ölü Gömme Gelenekleri (2000) adlı eserlerini bu babda anabiliriz. Osman Turan Özel Sayısı'nda ise bu konuyu Türkiye Selçuklu Tarihi açısından inceleyen bir makale yer almaktadır: Dr. Emine Uyumaz’ın 'Selçuklu Türkiye'sinde Defin ve Taziye Merasimlerine Dair” isimli makalesinde (s. 139-253) XI-XIV. asırlar arasında Türkiye Selçukluları ve Beylikler döneminde defin öncesi ve sonrası cenazenin hazırlanışı, yas ve matem süresi boyunca icra edilegelen örf ve âdetler ele alınmış, bu âdetler dinler tarihi açısından da gözden geçirilerek, İslâmiyet öncesi ve sonrası defin ve taziye gelenekleri ve bunların Bizans gelenekleriyle benzerliği karşılaştırmalı olarak ortaya konulmuştur.

Dr. Emine Uyumaz'ın makalesiyle Özel Sayı'da makalelere ayrılan sayfalar sona ermektedir. Peşinden bir perde sayfasıyla ayrılan "Mülâkat / Kitabiyat" sayfaları başlamaktadır. Sayının "mülâkat”a ayrılan kısmında Doç. Dr. Salih Yılmaz ve Arş. Gör. Murat Nalçacı'nın gerçekleştirdiği "Doğumunun 100. Yılında Prof. Dr. Ali Birinci’nin anlatımıyla Prof. Dr. Osman Turan” başlıklı röportaj (s. 157-177) yer almaktadır. Prof. Birinci'nin Osman Turan'ın kapsamlı bir biyografisini kaleme aldığı ve Osman Turan'ı konu alan bir kitaba imza attığı bilindiğinden, Yılmaz ve Nalçacı'nın “Doğumunun 100. Yildönümünde Osman Turan'? anmak ve onu farkh yönleriyle tantmak amacyyla kendisiyle belli bir mesaisi olmuş bir şahsiyetle söyleşi yapmak” (s. 157) amacıyla Prof. Birinci'ye yönelmiş olmaları isabetli olmuştur. Birinci, bu röportajda sorulan sorular üzerine, şahsî hâtıralarını dile getirdiği kadar Osman Turan'mn akademik hayatı, siyasete atılışı, Türk Tarih Kurumu üyeliğine seçilişi ve üyelikten çıkartılışı, eserleri ve yazıları ve hemen her yönüyle ilgili bilgiler de vermiştir.

"Bir Belge" kısmında Zeki Velidî Togan’’n Atatürk’e yazdığı mektubun metni (haz. Celil Güngör, s. 179-180) ve kitap tanıtmalarına ayrılan sayfalarda ise üç kitabın tanıtımı yer almaktadır. Tanıtmaların ilki Fatih Gökdağ’ın kaleme aldığı "Gecikmiş Bir Eser: Türkiye Tarihi Selçuklular Deori (1. Cilt)” başlıklı yazıdır ve Türk Tarih Kurumu Yayınları arasında ilk cildi basılan Mükrimin Halil Yinanç’ın yıllardır bir bütünlük içinde yayınlanmayı bekleyen eserini konu almaktadır (s. 181-182). Bu eserin ikinci cildi de yine Türk Tarih Kurumu Yayınları arasında Aralık 2014'te basılmış bulunmaktadır. Yine Ali Birbiçer, Hüseyn b. Ali b. Hüseyn el-Leysî el-Vâsıtî'nin Kûtü'l-Ervâh ve Kâkûtü'l-Erbâh adlı eserini tanıtmaktadır (s. 183-192). Tanıtma yazısından anlaşıldığı kadarıyla eser, İslâm tarihi kaynaklarında 
teâmül olduğu üzere "hilkat”'ten başlayıp peygamberler, Hz. Muhammed'in hayatı, Dört Halife devri, Emevîler ve Abbâsîler’i işleyerek İlhanlı hükümdarları (Abaka Han, Sultan Ahmed, Geyhatu, Baydu, Gazan Han, Hudâbende, Ebû Saîd) hakkındaki bölümlerle sona ermektedir. Eser, Selçuklu ve İlhanlı tarihi açısından dikkate değer Arapça yazma bir tarih kaynağıdır. TYB Akademi dergisinde tanıtmalara ayrılan son sayfalarda ise Doç. Dr. Albek Abazov'un "Aralıkçılardan V. P. Romanov'un Bilinmeyen El Yazma Eseri “Abhaz Sözlüğü” başlıklı yazısı yer almaktadır (s. 193-196).

Dergi, akademik süreli yayınlarda âdet olduğu üzere katkıda bulunan yazarların özgeçmişlerine ayrılan sayfalarla sona ermektedir.

Prof. Osman Turan gibi Türk Tarih Kurumu Yayınları arasında biri metin neşri, biri editoryal olmak üzere toplam beş eserde imzası bulunan, çalışmaları hâlâ Selçuklu tarihi araştırmalarını besleyen bir tarihçimizin 100. Doğum Yıldönümü için yayımlanan bu Özel Sayı bir vefa örneği sayılmalıdır. Türk Tarih Kurumu da 100. Doğum Yıldönümüne denk gelen 2014 yılı içinde Prof. Dr. Osman Turan'ın başta TTK-Belleten olmak üzere çeşitli akademik dergilerde yayımlanmış makalelerinden derlenen Selçuklu Tarihi Araştırmalar (haz. Altan Çetin-Bilal Koç, Ankara 2014, X + 601 s.) adlı eserini yayınları arasına katmış ve daha önce yayınları arasında basılan ve baskısı tükenmiş bulunan Türkiye Selçuklulan Hakkında Resmî Vesikalar: Metin, Tercüme ve Araştırmalar (1. bsk. 1958 ve 2. bsk. 1988) künyeli eserini de 2014 içinde yeniden yayımlamıştır.

Merhum Prof. Dr. Osman Turan'ın Türk Tarih Kurumu Yayınları arasında daha önce İstanbul'un Fethinden Önce Tazılmış Tarihî Takvimler (1. bsk. 1954; 2. bsk. 1984 ve 3. bsk. 2007) künyeli eseri ile mukaddime ve haşiyelerle tashih ve neşri Osman Turan tarafindan gerçekleştirilen Aksaraylı Mehmed oğlu Kerîmüddin Mahmud’un Müsâmeret ül-Ahbâr: Moğollar Zamanında Türkiye Selçuklulan Tarihi (1. bsk. 1944; 2. bsk. 1999) adlı çalışması ile editörlüğ̈nü yaptı̆̆1 60. Doğum Yil Münasebetiyle Fuad Köprülü Armağan = Mélanges Fuad Köprülü (Doğumunun 120. Yılı münasebetiyle tıpkıbasım, TTK Yayınları, 2010) adlı kitap da basılmıştı. İlk kez derlenerek basılan Selçuklu Tarihi Araştırmalar hariç her biri birkaç baskıya ulaşmış bulunan bu eserler üniversitelerimizde kaynak kitap olarak hâlâ kullanılmakta ve ilim erbabının araştırmalarına katkı sağlamaya devam etmektedir.

Yusuf Turan GÜNAYDIN

Türk Tarih Kurumu 